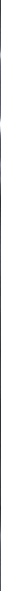

\title{
An investigation into adhesives to consolidate distemper paintings on canvas
}

\author{
Cristina Castro Simarro
}

\begin{abstract}
This article investigates traditional and modern adhesives used to consolidate distemper paintings on canvas, with special reference to sixteenth century Hispano-tüchlein paintings, also called sargas. Such artworks are not only difficult to handle due to their large size, but they are also inherently fragile and/or are highly hygroscopic. This sensitivity is caused in part by the nature of the painting technique as well as the lack of varnish, which might account for why conservation methods related to these works have not been addressed in the past. This investigation was conducted on historical reconstructions samples to assess and develop treatment strategies for distemper paintings, in particular issues linked to powdery/friable matte paint layers. The impact of several adhesives on the painted surface of historical reconstructions was evaluated before and after the samples were subjected to humidity cycling tests using a range of analytical techniques. Such information can be used to aid conservators who face consolidation issues related to underbound paintings or artworks with similar surfaces. The results reveal that there is no one perfect adhesive for matte paint nor one that can be removed completely, once applied. Aquazol ${ }^{\circledast} 200$ and Funori performed the best, but still introduced changes in colour and gloss, even if minimal.
\end{abstract}

Keyword: sargas, canvas paintings, conservation, consolidation, adhesives, matte paint

\section{Investigación sobre adhesivos para consolidar pinturas al temple sobre lienzo}

Resumen: Este trabajo trata de evaluar algunos de los adhesivos tradicionales y modernos utilizados para consolidar pinturas al temple de cola sobre lienzo, especialmente aquellas pertenecientes al siglo XVI, también llamadas sargas o tüchlein. Tales obras de arte no solo son difíciles de manipular, en ocasiones debido a su gran tamaño, sino que también son inherentemente frágiles y / o altamente higroscópicas. Esta sensibilidad se debe en parte a la naturaleza de la técnica empleada para llevar a cabo este tipo de pintura, así como a la falta de barniz, lo que podría explicar por qué los métodos de conservación relacionados con este tipo de obras no se han abordado en el pasado en muchos casos. Esta investigación se realizó mediante el uso reconstrucciones históricas para evaluar y desarrollar estrategias de tratamiento para temples de cola sobre lienzo, concretamente relacionadas con los problemas de consolidación que presentan en superficie y tratarse de pinturas mate. Se ha evaluado, utilizando varias técnicas analíticas, el impacto de varios adhesivos en la superficie pintada antes y después de someter las muestras a varios tests con ciclos de humedad distintos. Dicha información se podría emplear para ayudar a los conservadores-restauradores que se enfrentan a problemas de consolidación relacionados con pinturas pulverulentas u obras de arte con problemas de consolidación superficial similares. Los resultados revelan que no hay un adhesivo perfecto para consolidar pintura mate ni uno que pueda eliminarse por completo una vez aplicado. Aquazol ${ }^{\circledR} 200$ y Funori son los adhesivos que obtuvieron mejores resultados, pero aun así introdujeron cambios en el color y el brillo, si bien fueron mínimos.

Palabras clave: sargas, pintura sobre lienzo, conservación, consolidación, adhesivos, pintura mate

\section{Investigação sobre adesivos para a consolidação de tintas a têmpera em tela}

Resumo: Este trabalho procura avaliar alguns dos adesivos tradicionais e modernos usados para consolidar pinturas a têmpera de cola sobre tela, especialmente aquelas pertencentes ao século XVI, também chamadas de sargas ou tüchlein. Essas obras de arte não são apenas difíceis de manusear, às vezes devido ao seu grande tamanho, mas também são inerentemente frágeis e / ou altamente higroscópicas. Esta sensibilidade deve-se em parte à natureza da técnica utilizada para a realização deste tipo de pintura, bem como à falta de verniz, o que poderia explicar o motivo pelo qual os métodos de conservação relacionados com este tipo de obra não foram contemplados no passado, em muitos casos. Esta investigação foi realizada mediante o uso de reconstruções 
históricas para avaliar e desenvolver estratégias de tratamento de têmperas de cola sobre tela, especificamente relacionadas com os problemas de consolidação que apresentam na superfície e o tratamento de tintas mates. O impacto de varios adesivos na superfície pintada foi avaliado recorrendo-se a várias técnicas analíticas antes e depois de submeter as amostras a vários testes com ciclos de humidade distintos. Essa informação podia ser empregue para ajudar os conservadores-restauradores que enfrentam problemas de consolidação relacionados com pinturas pulverulentas e obras de arte com problemas de consolidação superficial similares. Os resultados revelam que não há um adesivo perfeito para consolidar pintura mate nem um que possa ser eliminado por completo após a aplicação. Aquazol ${ }^{\circledR} 200$ e Funori são os adesivos que apresentaram melhor desempenho, mas ainda assim introduziram alterações de cor e brilho, embora mínimas.

Palavras-chave: sarja, tinta sobre tela, conservação, consolidação, adesivos, tinta mate

\section{Introduction}

Related to the use of the canvas as a painting support and technical advances in painting, the development of sargas is situated in a context where profound technical, aesthetic and even intellectual changes are being experienced.

One of these major changes in the evolution of the painting was the transition from wood panels to canvas supports. The transition to canvas supports made feasible the sumptuous textiles used for decoration in celebration events and complex religious liturgies since panels were limited to certain sizes. Sargas are the forerunners of this widespread use of canvas-style support from the end of the fifteenth century (Levenfield 1992). Their characteristics are intimately connected to their functionality and not to their durability since the majority of the works have an ephemeral and fragile nature, which has been the main cause of their deterioration or disappearance.

In the Low Countries, this type of painted textile appears to have emerged in the fourteenth century and was called tüchlein by Albrecht Dürer in his travel journals (Wolfthal 1989; Castell 2002). Tüchlein refers to a gluetempera painting, generally with a fine linen canvas support, without priming and often without a ground (Wolfthal 1989; Bruquetas 2002; Castell 2002; Muller 2011). Their execution increased greatly in the $15^{\text {th }}$ and 16 th centuries, before beginning to decline when the use of oil became more popular in painting. In this geographic area there was an intensive production process, which was practically industrial and was exported to other places such as England, Italy and Spain (Levenfield 1992; Santos and San Andrés 2004). However, this type of painting technique, mainly Lenten veils, became practically extinct in England after the Reformation in the time of Henry VIII while in Germany and its zone of influence the production was interrupted after the Lutheran Reform. By contrast, in Italy, an artist as important as Andrea Mantegna practised this technique; but it was especially in Spain and Austria where this painting tradition was kept alive until the late 18th century, disappearing as a liturgical element after the Second Vatican Council (1959-1965) (Buces 2001).
The artistic link between Castile and Flanders and the close commercial relationships created at the end of the fifteenth century to the middle of the sixteenth century, favoured the exchange of the majority of the painting materials. At that time, there was an extraordinary development of the artworks export, mainly localised in Mechelen, Antwerp and Bruges among other places where there were notable factories of distemper paintings (Bruquetas 2002:120). This explains why these artworks were also known in Spain as telas de Flandes, Flemish canvases/cloths. Further, political dominions, business, as well as family connections between monarchs were exploited in the supply of these artworks. The powerful links between the south of Italy, the Low Countries, Spain and the German Empire, all under control the king Charles $\mathrm{V}$ of Habsburg encouraged commerce and resulted in the development of a great artistic trade between these areas.

This study, based at Northumbria University aimed to establish conservation procedures for sargas, and to formulate treatments and materials for early canvas paintings that are large, underbound and fragile. Like tüchlein, sargas are not often regarded as first-class works of art (Bomford et al., 1986), although distemper on canvas has been recognized as a common technique for paintings produced by leading artists, such as Dürer (Hess and Eser 2012), Justus of Ghent (Scully and Seidel 2016), Brueghel "The Elder" (Finaldi and Silva Maroto, 2011), Dieric Bouts (Bomford et al. 1986; Leonard et al.1 988), Andrea Mantegna (Carr 1997) and Quentyn Massys (Roy 1988), among others (Wolfthal 1989; Silva Maroto 1990; Villers 2000; Costaras and Young 2013).

The physical deterioration of sargas can be linked to water sensitivity (Wrubel, 2002), as well as to handling and extensive wear, usually noticeable in folded areas and creases (Castell et al. 2006). As a consequence of their fragility, these paintings are commonly kept in storage and are more often preserved rather than conserved. Thus, there is significant lack of knowledge about conservation methods for sargas (García 1991; Renard et al. 1991; Buces et al. 1992; Borrego et al. 2001). This investigation aimed to address this gap by creating accurate reconstructions 
of degraded black distemper paint based on historical treatises. Another aim was to study and test different consolidation materials and procedures. Furthermore, changes on surface appearance were assessed before and after exposing them to two different cycles of humidity to study the behaviour of consolidants in uncontrolled environments. According to Hansen et al. (1993:1), there is a lack of case studies where theoretical concepts have been developed into practical tests or actual treatments of paintings. This deficit of applied literature complicates the reconstruction of samples to develop treatment strategies for the particular issues that affect this type of painting.

\section{Rationale}

\section{-Preparation of Samples}

The preparation of samples was based on historic recipes employed to paint sargas cited in treatises of Felipe Nuñez (cited in Véliz 1986) and Francisco Pacheco (1649), as well as on recent articles that describe methodologies to recreate matte powdery paint samples (Hansen et al. 1993; Michalski et al. 1998; Geiger and Michel 2005). In their preparation it was taken into account that despite some artworks present a ground, usually those belonging to the $14^{\text {th }}$ and $15^{\text {th }}$ centuries, the Ordenanzas de Madrid of 1543 (cited in Santos an San Andrés 2004) and authors such as Nuñez (cited in Véliz 1986), Vasari, Volpato (both cited in Santos and San Andrés 2004) and Palomino (1715-24) do not consider this procedure in their making process. Even Francisco Pacheco in his treatise El Arte de la Pintura (1649) alludes to their bad effects in long term.

Also, a comparative study was undertaken of different traditional and modern adhesives and established methodologies for the consolidation of matte paint (Hansen and Lowinger 1990; Dignard et al. 1997; Michalsky and Dignard 1997; Geiger and Michel 2005; Ebert et al. 2012) to evaluate their efficacy, workability and performance. Two methods were employed to apply the adhesives onto the samples: with a brush (Calvo et al. 2002; Villarquide 2005; Michel 2011; Von der Goltz et al. 2012; Thuer 2012); and by spray (Welsh 1980; Villarquide 2005).

\section{- Consolidants and Methods Selection}

Initial tests were limited in scope and time. Therefore, only a selection of consolidants was tested. All consolidants were chosen according to their ideal properties. The results were applied to matte paint conservation processes observed in literature.

Aquazol $^{\circledR}$, poly (2-ethyl-2-oxazoline), was selected as it has been characterized as an adhesive with a good strength and mechanical stability (Wolbers et al. 1998;
Lechuga 2009, 2011). It is thermally stable, non-toxic and not affected by mold growth. It is retreatable in various solvents, has a neutral $\mathrm{pH}$ and remains flexible once dry and aged (Wolbers et al. 1998; Arslanoglu 2003; 2004; 2005; Colombo et al. 2015; La Nasa et al. 2017). Higher molecular-weight types of Aquazol $^{\otimes}$ (200 and 500) dissolved in 1:1 solution of de-ionised water (DW) and propan-2-ol have been successful for consolidating matte paint (Arslanoglu 2003; Ebert et al. 2012; Colombo et al. 2015).

The second adhesive was Paraloid ${ }^{\circledR}$ B72, a polyacrylate solution introduced in the 1960's by Rohm and Haas, as there is literature (Welsh 1980; Hansen et al. 1993) supporting its use as a consolidant for powdery paint, mixed in diethyl benzene. However, due to availability, xylene was employed instead of diethyl benzene.

Finally, Isinglass ${ }^{\circledR}$, a refined grade of fish glue made from the dry swim bladders of the sturgeon fish, and Funori, a polysaccharide-based adhesive that is extracted from some red seaweeds species of Gloiopeltis genus (Swider and Smith 2005; Catenazzi 2016), were also tested. Both organic adhesives, mixed in polar solvents, have long been used successfully to consolidate underbound matte paint (García Gómez-Tejedor 1991; Geiger and Michel 2005; Swider and Smith 2005; Horie 2010; Sartiani et al. 2010; Michel 2011; Andrina 2014; Catenazzi 2016; Sharpe 2016).

\section{—Selection Process of the Application Methods}

In this study, an attempt was made to test different concentrations of solutions prepared with low volatility solvents, and used in up to ten applications to minimize the risk of visible film formations. In the literature multiple applications of dilute solutions were shown to be more effective than using just one concentrated solution (Maheux and McWilliams 1995; Michalski and Dignard 1997; Michel, 2011; Ebert et al. 2012). Therefore, although successful methodologies for consolidating friable paint have been based on the use of an ultrasonic mister or similar (Maheus and McWilliams 1995; Dignard et al. 1997; Michalski and Dignard 1997; Michalski et al. 1998), these techniques were not adopted for these tests as this work required only very low concentration solutions of adhesive. Other methodologies combine the brush application with the use of low pressure tables, but since this investigation intended to find a methodology to deal with large format distemper paintings and in various scenarios, a low pressure table was not appropriate. Finally, some recent methodologies propose nanocomposite coatings based on $\mathrm{TiO} 2$ nanoparticles and Aquazol $^{\circledR}$ to consolidate matte paint (Colombo et al. 2012). However, these tests were performed on the surfaces of modern and contemporary paintings, made with young oils or acrylics. These were not recommended for hygroscopic paintings (Colombo et al. 2015: 6). 


\section{— Analysis and Evaluation of the Performance of Adhesives}

With the aim of assessing the impact of the adhesives on the painted surface, samples were evaluated under a stereomicroscope to observe the deposition of the adhesives on the paint layer and detect potential alterations. Glossimetry and colourimetry were also used to examine changes in surface appearance and the impact of the treatment before and after the samples were exposed to two humidity cycles. Moreover, Ultraviolet (UV) Fluorescence and Scanning Electron Microscopy (SEM) monitored changes before and after consolidation.

A Leica S6 D Greenough stereomicroscope was used to evaluate morphological changes between un-treated and treated surface areas. Lighting was adjusted with a gooseneck LED light fibre (KL 300 LED, SCHOTT) and digital images were captured with a Leica MC170 HD camera attached to the microscope. Paint cross-sections before and after consolidation were studied with an Olympus BX51M Optical Microscope (OM) in reflected visible (VIS) and ultraviolet fluorescence (UV-F) with a $\times 10$ eyepiece lens and objectives up to $\times 100$. An attached Olympus DP70 digital camera recorded micrographs. These cross-sections were employed to note how the unbound pigment was accommodated on the samples' surface and to measure the thickness of the pigmented layer.

UV-F photographs were used to assess changes before and after consolidation procedures and were recorded with a Cannon 6D EOS camera, blacklight blue (BLB) tube lights and a Kodak Wratten $2 \mathrm{E}$ adjusted to the camera lens to cut off wavelengths below $415 \mathrm{~nm}$. The aperture was adjusted to $\mathrm{f} / 8$ and the Kelvin (K) White Balance setting that allowed to adjust the white balance of the image files in the computer screen. The lights were placed at $30^{\circ}$ to the surface.

Gloss was monitored with a Rhopoint IQ glossmeter that recorded gloss units (GU) while colour change was measured with a Konica Minolta CM-2600d colorimeter recording in the CIE L*a*b* colour space. Three measurements were taken in each sample for accuracy.

\section{A high resolution Tescan FE-SEM MIRA3 Scanning Electron Microscope was employed to study the topography of the consolidated paint surfaces. Thin sections of the samples were extracted with a scalpel blade (No15) and adhered to $12.5 \mathrm{~mm}$ diameter aluminium studs with carbon adhesive disks. The samples were sputter coated with a platinum layer $8 \mathrm{~nm}$ thick at $4 \times 10-2 \mathrm{mbar}$ in Quorum Q150R ES to reduce charging and then recorded with $5 \mathrm{kV}$ and $1.5 \mathrm{kV}$ acceleration voltage and magnifications ranging from 1000x and 5000x.}

\section{— Selection Process of Relative Humidity Cycles}

To identify a consolidant that is the best to secure friable paint, it is important to know the surface response of the painting to temperature and humidity fluctuations. Thus, the samples were subjected to two relative humidity cycles to evaluate the efficacy of the adhesives in uncontrolled environments. The cycles were based on previous studies that investigate the same types of consolidation processes for matte paint (Catenazzi, 2016; Geiger and Michel, 2005). Conditions will be described in section 3.2.3.

\section{Experimental}

\section{- Materials}

Historical reconstructions were made from tabby-weave linen, $13 \times 10$ threads per $\mathrm{cm} 2$ with an isolation layer of glue-size made of size $5 \%$ wt rabbit-skin glue (CTS Europe ${ }^{\oplus}$ 01112005) in de-ionised water (DW). Lamp black (Manuel Riesgo S.A $A^{\oplus}$ PI602/0250) and charcoal pigments (Kremer ${ }^{\circledast}$ 47800 ) were bound in $5 \%$ wt rabbit skin glue in DW.

With regard to the selection of the pigments, it has been observed that distemper grisailles made with black, white and sometimes ochre colours were abundant. Being black one of the most representative colours in their palette, two commercial types of carbon black were chosen to make the reconstructions. Also, when consulting technical reports performed on sargas from the $15^{\text {th }}$ and $16^{\text {th }}$ centuries, the presence of carbon black was observed but without accuracy on the type of pigment. A study by Tomasini et al. (2012) states that lamp black, commercial charcoal, and also bitumen are characterized by their high content of carbon (>85\%). Lamp black would be only differentiated from bitumen and charcoal by the presence of sulphur, presumably from heterocyclic aromatic hydrocarbons.

Consolidation tests were prepared with different solutions of Isinglass ${ }^{\oplus}$, Funori, Aquazol ${ }^{\circledR} 200$ and 500, and Paraloid ${ }^{\oplus}$ B72 in propan-2-ol, xylene and DW (see table 1 in results). These were tested in combination with a high wet strength, unbuffered, long 100\% Manila fibre tissue and Tarantula paper (9.3gsm, Conservation by Design $\left.{ }^{\oplus}\right)$. Additional equipment included a bristle brush (No 75) and synthetic soft brushes (No 10, 6 and 4).

\section{-Methodology}

\section{- Reconstructions of Sargas}

Two traditional wooden looms $(96 \mathrm{~cm} \times 124 \mathrm{~cm} \times 4 \mathrm{~cm}$, and $89 \mathrm{~cm} \times 135 \mathrm{~cm} \times 3.3 \mathrm{~cm}$ ) were prepared and two sheets of linen ( $65 \mathrm{~cm} \times 110 \mathrm{~cm}$ each) were sewn with cords previously coated with wax. The fabrics were de-crimped four times, re-stretched manually and left to dry. Then, the $5 \% \mathrm{w} / \mathrm{v}$ rabbit-skin glue size was applied with a brush to the canvas. The paint was prepared by blending the same warm gluesize solution and lamp black pigment using a glass muller, a metal spatula and a syringe until a consistent paste was achieved. Finally, the paint was brushed on top with a bristle brush. 
Once the canvas dried, it was removed from the loom and cut into $5 \mathrm{~cm} \times 5 \mathrm{~cm}$ pieces. The production of underbound pigments was based on Geiger and Michel's methodology (2005). The pigments were sieved and stirred in DW for 24 hours, then filtered through a fine muslin. One coat was applied to the samples with a brush. The thickness of the dry pigmented layer ranged between $100 \mu \mathrm{m}$ and $150 \mu \mathrm{m}$, observed with an optical microscope in a cross section.

\section{- Consolidation Tests}

Consolidation processes are necessary to reattach the fragile or flaking paint to the support and avoid their loss. Aquazol $^{\circledR}, 200$ and 500, Paraloid ${ }^{\circledR}$ B72, and Isinglass ${ }^{\circledR}$ resins were employed for the making consolidation adhesives at three different concentrations: $1 \%, 3 \%$ and $5 \%$ weight/ volume $(w / v)$ in the appropriate solvent (see table 1). Moreover, $0.2 \%, 0.6 \%$ and $1 \% \mathrm{w} / \mathrm{v}$ Funori in DW were tested.

The underbound pigment layer was consolidated firstly by brushing (synthetic soft brushes No 10, 6 and 4) the different consolidation solutions on to the samples surface through a $5 \mathrm{~cm} \times 5 \mathrm{~cm}$ thin Tarantula $^{\circledR}$ tissue paper. Each adhesive was applied at room temperature and left to dry overnight except Isinglass ${ }^{\circledR}$ and Funori, which were applied warm (55० $\left.-63^{\circ} \mathrm{C}\right)$.

The progress of the consolidation was visually tested by observing the quantity of powder remained adhered on the tissue after each coat. Therefore, the facing tissue was removed using DW except for the Paraloid ${ }^{\circledR}$ B72 tests, where the tissue was not sufficiently adhered to the surface and was easily removed without employing any solvent.

On the other hand, consolidation procedures by spray were performed in a room conditioned with $48 \% \mathrm{RH}$ and $15.3^{\circ} \mathrm{C}$ and samples were not faced. In this case, temperature and relative humidity changed significantly to a $21.3 \% \mathrm{RH}$ and $31.4^{\circ} \mathrm{C}$ when the extraction system turned on. A spraypressure of 2.8 bars was selected when using the gravity fed spray gun. The sample board was situated on top of a small cart of $77 \mathrm{~cm}$ height and covered with a blotting paper cut just a few centimetres to allow the spraying of two samples at a time. Samples were sprayed with the nozzle in a vertical position at a distance of $60 \mathrm{~cm}$ in an angle of 900 and in horizontal bands over their surface during 3 - 4 seconds. Nevertheless, in case of Paraloid ${ }^{\circledR}$ B72 in xylene, as the extraction filters were attracting most of the adhesive, the angle of the spray gun was modified to 800 . The progress of the consolidation was visually evaluated by testing manually the effectivity of the adhesive in consolidating the underbound pigment on top of the samples after each coat up to ten coats.

The samples that were not sufficiently consolidated and remained powdery on surface were excluded from the subsequent relative humidity cycle tests.

\section{- Sample Exposure to Controlled Relative Humidity Cycles}

Two boards were prepared with the selection of consolidated samples (see table 1). Both sample boards were covered with blotting paper to contain the water and avoid potential shifting from moving water if bumped (Watkins, 2002). The samples were then exposed to relative humidity $(\mathrm{RH})$ cycles at room temperature to evaluate the durability and efficacy of the consolidation tests. The conditions varied from $40 \%$ to $75 \% \mathrm{RH}$, a wide spectrum so as to be representative in a variety of scenarios. Relative humidity values were based on similar methodologies where the same types of consolidation processes for matte paint were performed (Catenazzi, 2016; Geiger and Michel, 2005).

The first board was placed in a small humidity chamber, built for this purpose, at $70-80 \% \mathrm{RH}$, controlled using a hygrometer and a salt sodium chloride solution while the second was left at room temperature at $40-50 \% \mathrm{RH}$.

The first cycle lasted one week, with one board at a 40-50\% $\mathrm{RH}$ and another at $70-80 \% \mathrm{RH}$. The second cycle lasted three weeks at the same $\mathrm{RH}$ conditions.

\section{Results}

\section{- Consolidation Results}

All adhesives applied by brush were consolidated satisfactorily as opposed to those applied by spray. Only one sample was consolidated by spray and after ten applications: Aquazol ${ }^{\circledast} 5005 \% \mathrm{w} / \mathrm{v}$ in 1:1 v/v propan-2-ol and DW.

Although there were samples consolidated using Isinglass ${ }^{\circledR} 3 \%$ and $5 \% \mathrm{w} / \mathrm{v}$ in a $1: 1 \mathrm{v} / \mathrm{v}$ propan-2-ol and DW solution, they were discarded as some glossy, glue accretions appeared on surface and formed a noticeable whitish film.

In the case of consolidation with Paraloid ${ }^{\circledR}$ B72, clusters of consolidated pigments and glossy stains stem from difficulties during application with tissue paper in a fumed cupboard as the extraction system with air circulation caused pigment shifting.

Under the stereomicroscope, both Aquazol ${ }^{\circledR} 200$ showed a good consolidation and there was minimal darkening of the surface, while the canvas retained good elasticity. The $3 \% \mathrm{w} / \mathrm{v}$ blend increased the gloss as there were glossy stains visible on the surface due to eight coats of adhesive.

Regarding Aquazol ${ }^{\circledR}$ 500, both performed a better bond in comparison to Aquazol ${ }^{\circledR} 200$. The same observations as with $3 \%$ and $5 \% \mathrm{w} / \mathrm{v}$ Aquazol ${ }^{\circledR} 200$ were recorded under the stereomicroscope. The $5 \% \mathrm{w} / \mathrm{v}$ Aquazol $^{\circledR} 500$ 
Table 1.-Results after visual examination of brushed samples.

\begin{tabular}{|c|c|c|c|c|c|}
\hline Adhesive & Solvent & $\begin{array}{c}\text { Concentration } \\
(w / v)\end{array}$ & Number of coats & $\begin{array}{c}\text { Consolidation } \\
\text { Result }\end{array}$ & Appearance \\
\hline \multirow{3}{*}{ Isinglass ${ }^{\circledR}$} & \multirow{3}{*}{ DW } & $1 \%$ & 10 & poor & good \\
\hline & & $3 \%$ & 2 & good & white stains \\
\hline & & $5 \%$ & 2 & very good & glossy accretions \\
\hline \multirow{3}{*}{ Funori } & \multirow{3}{*}{ DW } & $0.2 \%$ & 10 & poor & good \\
\hline & & $0.6 \%$ & 7 & good & good \\
\hline & & $1 \%$ & 4 & very good & slightly darker, good \\
\hline \multirow{3}{*}{ Aquazol $^{\oplus} 200$} & \multirow{3}{*}{ 1:1 DW and Propan-2-ol } & $1 \%$ & 10 & poor & good \\
\hline & & $3 \%$ & 8 & good & very glossy \\
\hline & & $5 \%$ & 3 & very good & $\begin{array}{l}\text { minimal darkening, } \\
\text { slightly glossy }\end{array}$ \\
\hline \multirow{3}{*}{ Aquazol $^{\oplus} 500$} & \multirow{3}{*}{ 1:1 DW and Propan-2-ol } & $1 \%$ & 10 & poor & good \\
\hline & & $3 \%$ & 6 & good & $\begin{array}{l}\text { slightly darker, very } \\
\text { glossy }\end{array}$ \\
\hline & & $5 \%$ & 3 & very good & $\begin{array}{l}\text { barely darker, } \\
\text { slightly glossy }\end{array}$ \\
\hline \multirow{3}{*}{ Paraloid $^{\oplus}$ B72 $^{2}$} & \multirow{3}{*}{ Xylene } & $1 \%$ & 10 & poor & poor \\
\hline & & $3 \%$ & 10 & poor & poor \\
\hline & & $5 \%$ & 4 & good & $\begin{array}{l}\text { slightly dark and } \\
\text { glossy }\end{array}$ \\
\hline
\end{tabular}

darkened the surface more and became glossier than with $5 \% \mathrm{w} / \mathrm{v}^{\text {Aquazol }}{ }^{\otimes} 200$, but remained less glossy than with the $3 \% \mathrm{w} / \mathrm{v}$ Aquazol ${ }^{\circledR}$ 500. It darkened specifically the underbound pigment particles on surface Samples consolidated with the $3 \% \mathrm{w} / \mathrm{v}$ Aquazol $^{\circledR} 500$ became as glossy as those tested with the 3\% w/v Aquazol ${ }^{\circledR} 200$. In relation to canvas elasticity, the samples were more malleable and less brittle with the $3 \% \mathrm{w} / \mathrm{v}$ Aquazol $^{\circledR} 500$ than the $3 \% \mathrm{w} / \mathrm{v}$ Aquazol $^{\circledR} 200$.

Sprayed Aquazol ${ }^{\circledR} 500$ presented better elasticity when compared to the brushed sample. It also remained less glossy but the amount of underbound pigment on top was lower than in the brushed sample. Spraying of the surface ten times caused the loss of some pigments due to the pressured air.

Samples consolidated with Funori showed the fewest changes in appearance, leaving the paint more matte in comparison to the other consolidants tested. On the other hand, consolidation with Funori was weaker than with Aquazol $^{\circledR}$, as the Funori-consolidated paint was friable to the touch, more brittle and stiffened the canvas. Consolidation with $1 \% \mathrm{w} / \mathrm{v}$ Funori darkened the surface slightly and the results were similar to the $5 \%$ $\mathrm{w} / \mathrm{v}$ Aquazo $^{\otimes} 200$. The paint consolidated with $0.6 \%$ $\mathrm{w} / \mathrm{v}$ Funori retained its matte appearance more but with weakest adhesion.

\section{—Results after Relative Humidity Cycles}

Paint samples exposed to $75 \% \mathrm{RH}$ had variable results. Some samples increased in gloss after one week of exposure at $75 \% \mathrm{RH}$ and decreased after three. In contrast, others had a reduction in gloss after the first cycle of humidity and a minor increase after the second cycle.

On the other hand, $0.6 \% \mathrm{w} / \mathrm{v}$ Funori maintained the same value after the first week and doubled its gloss after the third week; as well as the brushed $5 \%$ w/v Aquazol ${ }^{\circledR} 500$.

Samples exposed to a $40 \%$ of relative humidity exhibited lower values of gloss in comparison to samples exposed to $75 \% \mathrm{RH}$.

Moreover, consolidation with $3 \%$ and $5 \% \mathrm{w} / \mathrm{v}$ Aquazol ${ }^{\circledR}$ 200 resulted in gradual gloss increase until over double the gloss values compared to before high humidity exposure.

The brushed $5 \% \mathrm{w} / \mathrm{v}$ Aquazol ${ }^{\circledR} 500$ was the only adhesive showing a considerable decrease in gloss throughout the total four weeks of exposure. It showed the most unpredictable changes in gloss under different $\mathrm{RH}$ conditions, while the sprayed sample performed the same behaviour under $40 \% \mathrm{RH}$ and $75 \% \mathrm{RH}$. The same happened with the brushed $3 \% \mathrm{w} / \mathrm{v}$ Aquazol $^{\circledR} 500$. The rest of the samples had random results. 


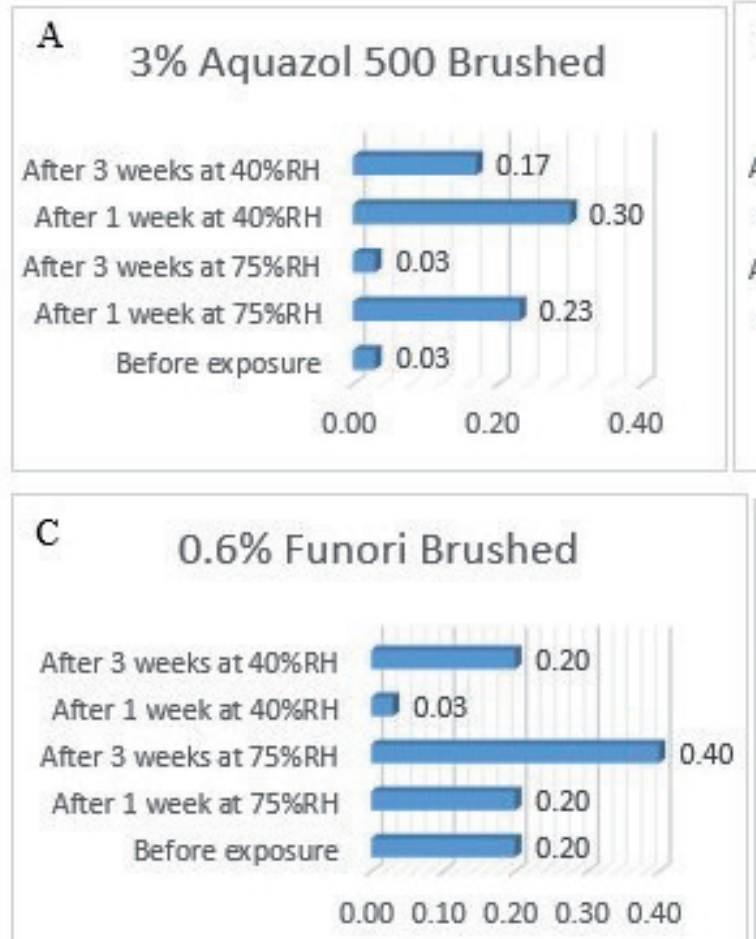

E 3\% Aquazol 200 Brushed

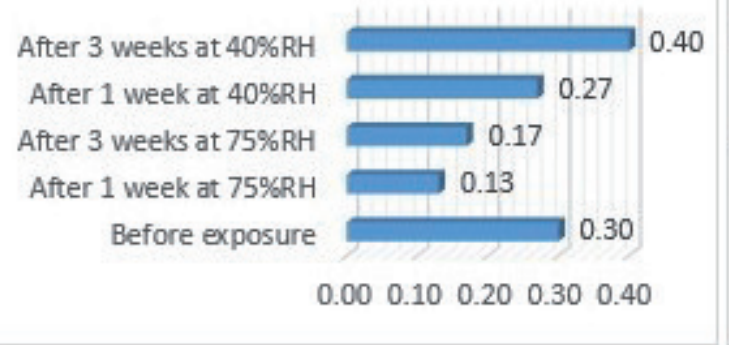

\section{G $5 \%$ Aquazol 500 Sprayed \\ After 3 weeks at $40 \%$ RH After 1 week at 40\%RH After 3 weeks at $75 \%$ RH After 1 week at 75\%RH Before exposure

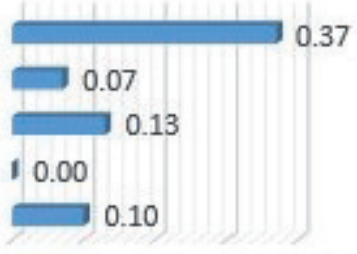 $\begin{array}{llllll}0.00 & 0.10 & 0.20 & 0.30 & 0.40\end{array}$}

\section{B $5 \%$ Aquazol 500 Brushed}

\section{D}

$1 \%$ Funori Brushed

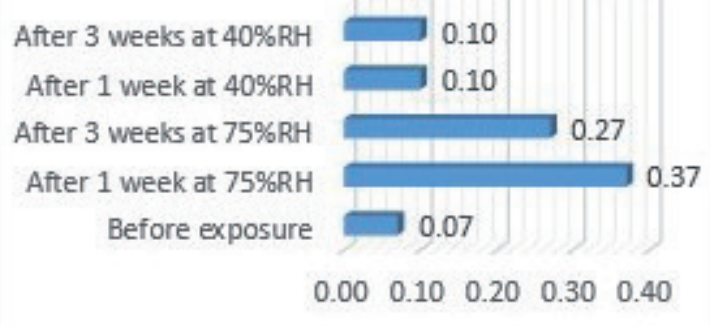

\section{F 5\% Aquazol 200 Brushed}

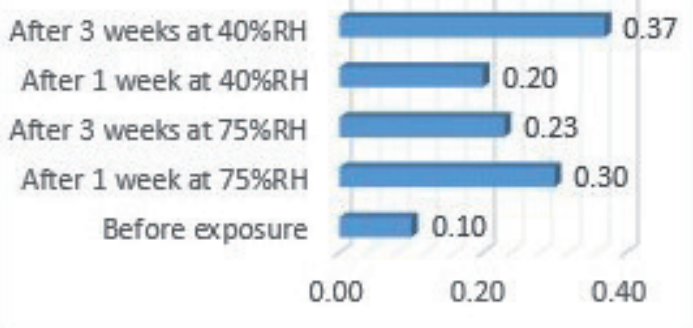

weeks at $40 \%$ RH

$0.20-0.40$

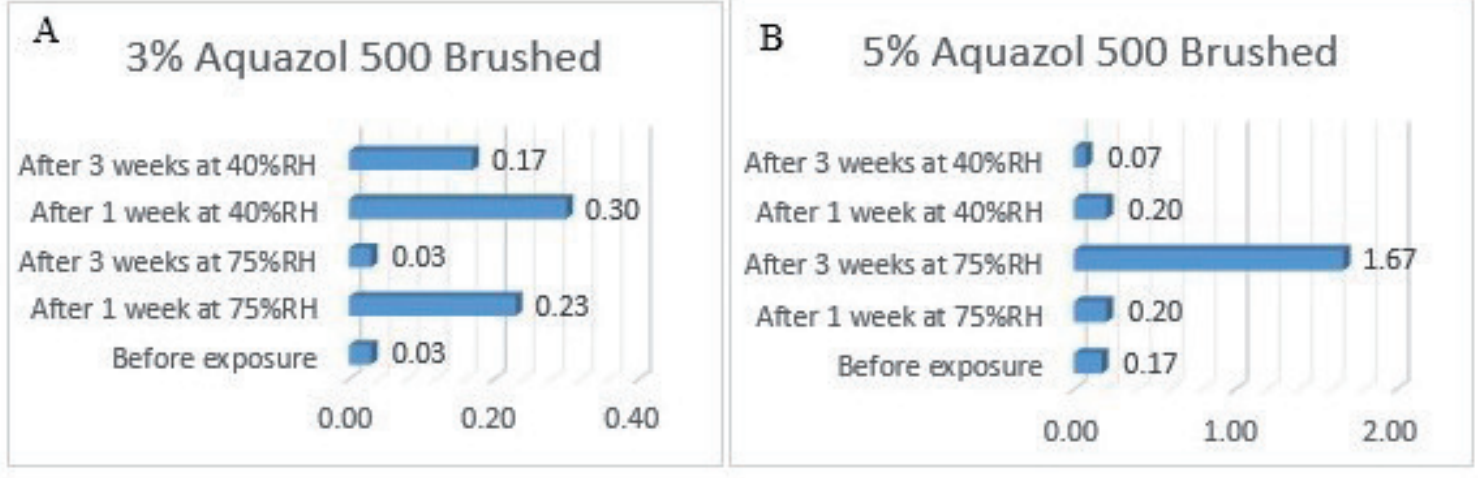

Figure 1.-Plots showing the combined average $85^{\circ}$ glossimetry data of samples exposed to two different cycles of relative humidity in gloss units (GU), at $40 \% \mathrm{RH}$ and $75 \% \mathrm{RH}$, during one and three weeks each. A. 3\% w/v Aquazol ${ }^{\circledR} 500$ Brushed. B. $5 \%$ w/v Aquazol ${ }^{\circledast} 500$ Brushed. C. 0.6\% w/v Funori Brushed. D. 1\% w/v Funori Brushed. E. 3\% w/v Aquazol 200 Brushed. F. 5\% w/v Aquazol ${ }^{\oplus} 200$ Brushed. G. 5\% w/v Aquazol ${ }^{\circledR} 500$ Sprayed.

\section{- Colourimetry Tests Results}

Changes in colour were observed to check if samples became yellower after the application of the adhesives and after subjecting them to the two different cycles of relative humidity. Results were very subtle as all of them were black. 
Results comparing raw samples and consolidated samples, prior exposure to humidity cycles, showed that all samples became brighter except for the one brushed $3 \%$ and $5 \% \mathrm{w} / \mathrm{v}$ Aquazol $^{\circledR}$ 500. However, when comparing samples before exposure and those exposed to one and three weeks of humidity cycles under $40 \%$ and $75 \%$ RH conditions, almost all became darker [Figures 2 and 3]. Exceptions that became brighter after the first cycle of humidity were: brushed $5 \%$ w/v Aquazol ${ }^{\circledR} 500$ exposed to $75 \%$ RH and sprayed $5 \%$ w/v
Aquazol $^{\circledR} 500$ exposed to $40 \% \mathrm{RH}$. Moreover, brushed 3\% w/v Aquazol ${ }^{\circledR} 500$ exposed to $75 \%$ and $40 \%$ RH, brushed $3 \%$ $\mathrm{w} / \mathrm{v}$ Aquazol ${ }^{\circledR} 200$ exposed to $40 \% \mathrm{RH}$ and brushed 5\% w/v Aquazol ${ }^{\circledR} 500$ exposed to $75 \%$ RH became brighter too after three weeks of exposure.

It is clear that the Aquazol ${ }^{\circledR} 500$ presented more fluctuations in terms of colour and gloss when subjected to different relative humidity conditions.

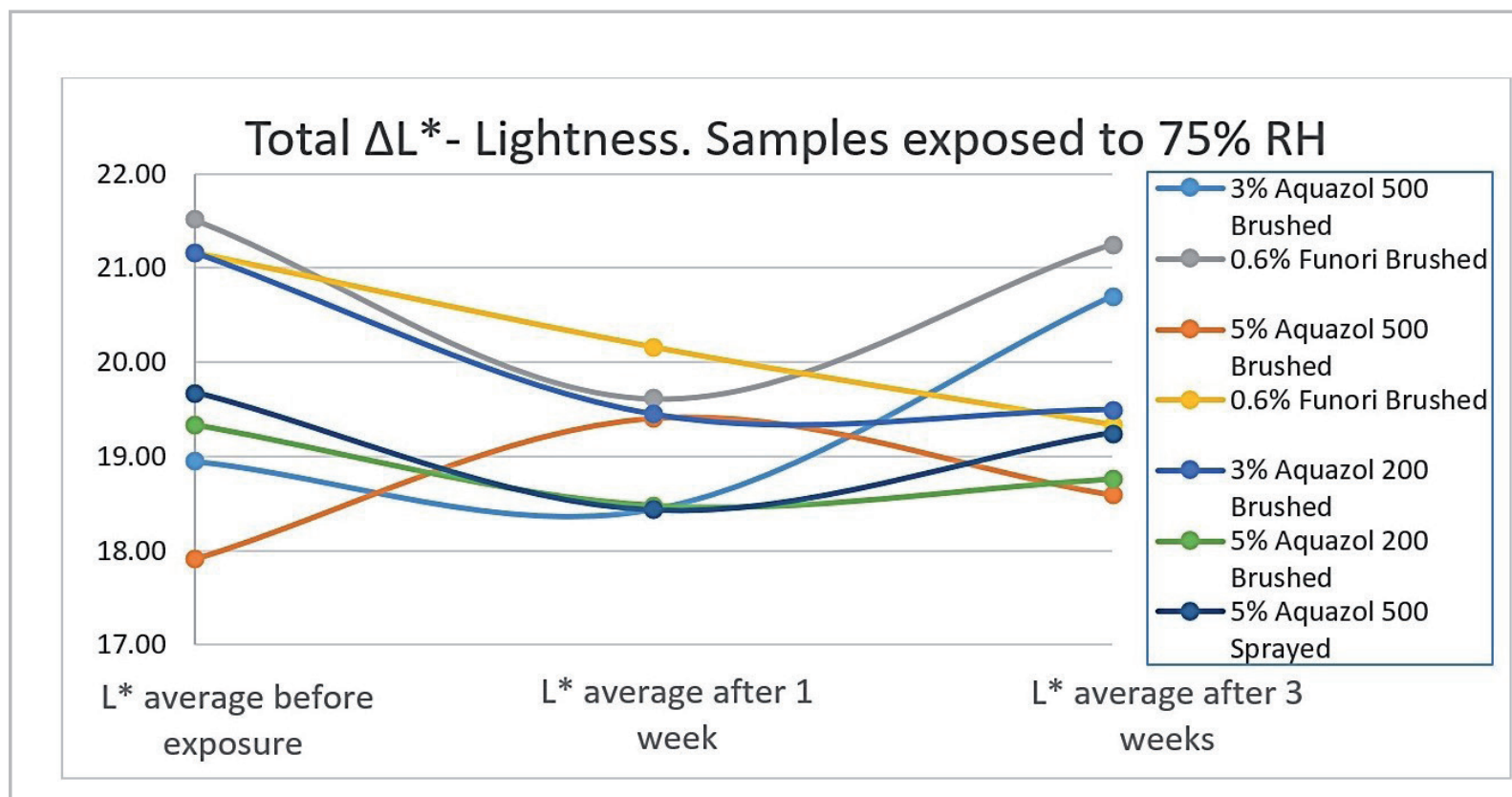

Figure 2.-Plot comparing $\Delta \mathrm{L}^{*}$ measurements of samples exposed to $75 \% \mathrm{RH}$ before and after two different cycles of 1 and 3 weeks.

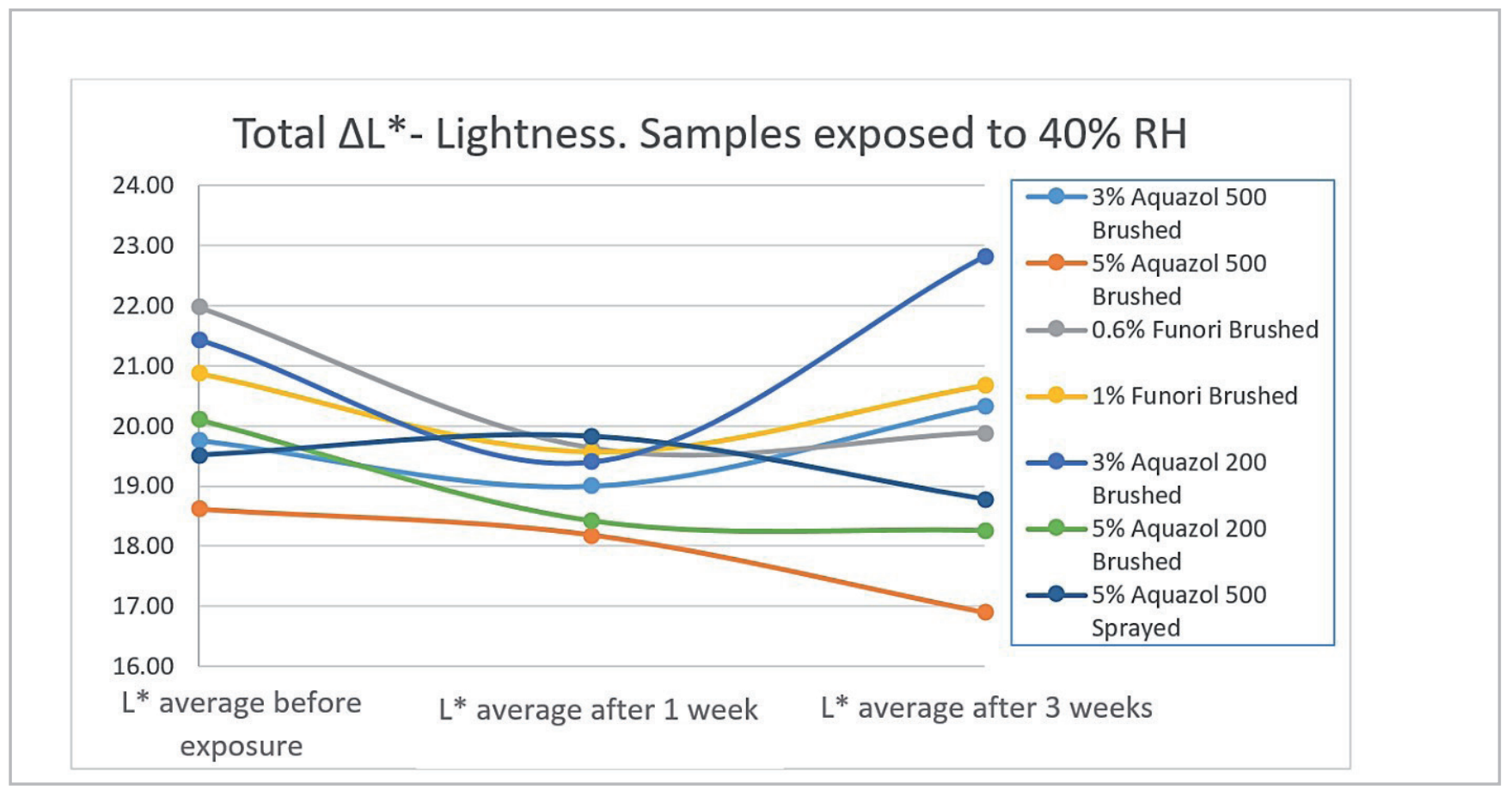

Figure 3.-Plot comparing $\Delta \mathrm{L}^{*}$ measurements of samples exposed to $40 \%$ RH before and after two different cycles of 1 and 3 weeks. 


\section{-Results of SEM}

Surface texture of samples exposed to $75 \% \mathrm{RH}$ for three weeks was evaluated by SEM, which clarified the correlation between the underbound pigments, the different adhesives, and the pores and voids on the surfaces of the consolidated samples. All samples formed films that appeared partially fragmented in some areas. This can be explained by the use of facings, which created fractures when they were removed. However, the same results were observed on the non-faced sample of sprayed $5 \% \mathrm{w} / \mathrm{v}$ Aquazol $^{\oplus} 500$ [Figure $4 A$ and $4 B$ ], which can perhaps be explained by the successive coatings applied to the sample (up to ten) and the method of application.

In addition, SEM showed that the thickness of the adhesive films depended on the number of coats. Only the $0.6 \% \mathrm{w} / \mathrm{v}$ Funori consolidant formed a continuous film [Figure 4C].

SEM also indicated the internal structures formed by the adhesives, as a honeycomb with circular voids varied in diameter, such as $3 \% \mathrm{w} / \mathrm{v}$ Aquazol $^{\circledR} 500$ [Figure $4 \mathrm{D}$ ] or $5 \%$ w/v Aquazol ${ }^{\circledR} 200$.

\section{DISCUSSION}

Given the unsatisfactory results for consolidation with Paraloid ${ }^{\oplus}$ B72 and Isinglass ${ }^{\circledR}$, this discussion will be limited to Aquazol ${ }^{\circledR}$ and Funori, which were the most efficient adhesives within this study. In addition, this study demonstrated that the brushed adhesives impregnated the facing tissue, the porous paint layer, the size, and the support, which implies that application method has implications for achieving strong consolidation throughout the stratigraphy of the painting. However, brushing also brings with it a higher risk of influencing the appearance of the paint, compared to the spraying technique. The sprayed $5 \% \mathrm{w} / \mathrm{v}^{\text {Aquazol }}{ }^{\circledR} 500$ adhesive did not penetrate into the painting structure, as it did when applied by brush, and the consolidation was less effective, as expected.
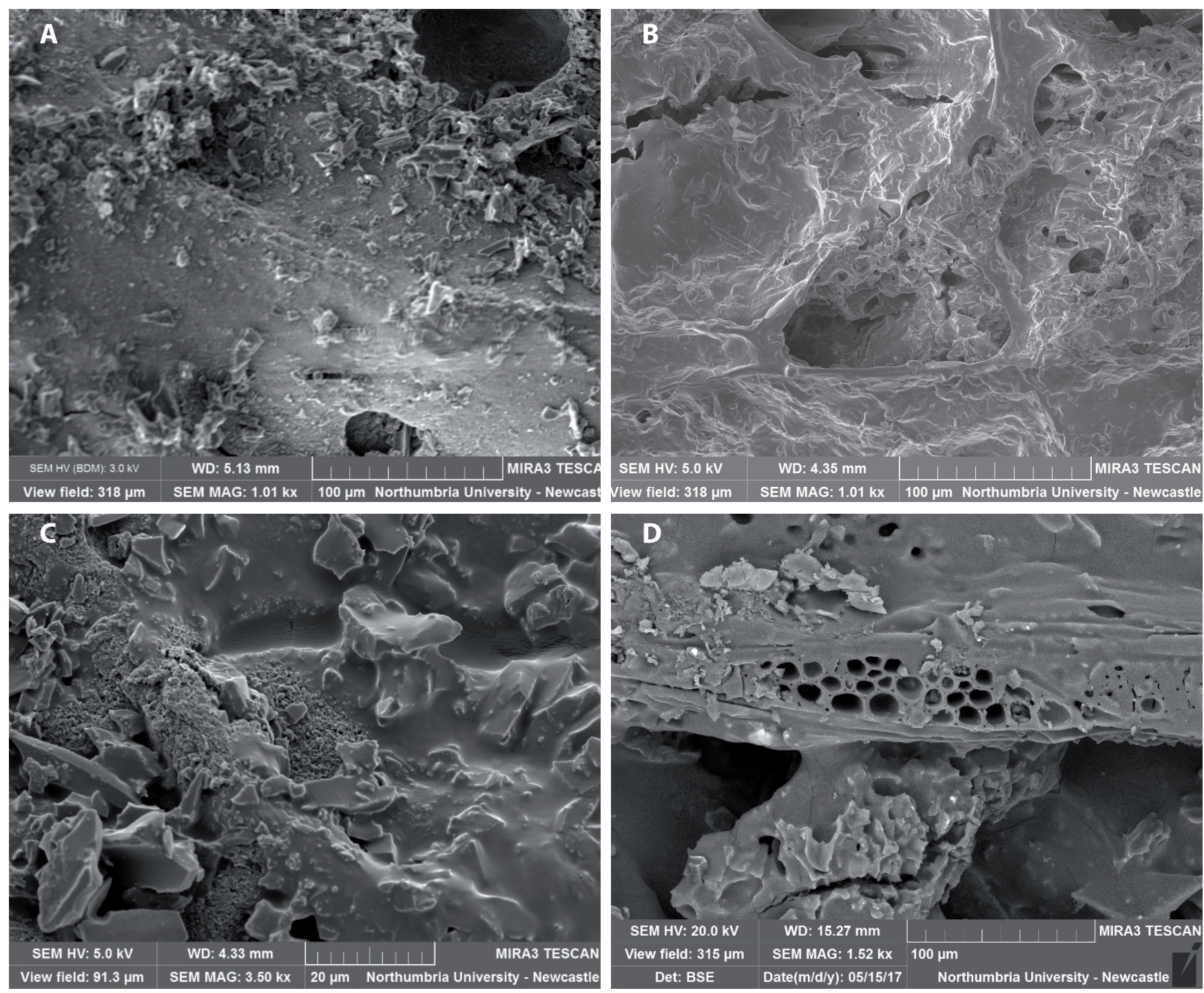

Figure 4.- A. Sprayed 5\% w/v Aquazol ${ }^{\oplus} 500$. B. Brushed $5 \% \mathrm{w} / \mathrm{v}$ Aquazol ${ }^{\oplus}$ 500. C. Brushed 0.6\% w/v Funori. D. Brushed 3\% w/v Aquazol $^{\circledR}$ 500. Photos taken under the SEM and subjected to cycles of $75 \% \mathrm{RH}$. 
Application with a brush of Aquazol $^{\circledR} 500$ diluted in a 1:1 DW and propan-2-ol demonstrated that viscous, high-molecular weight consolidant solutions can affect workability, depending on solvent choice, which affects application. Propan-2-ol has a moderate evaporation rate and polarity, as well as limited health and safety concerns; it also induced deeper penetration of the consolidant, so avoiding the formation of a glossy film.

Overall, the matte appearance was obtained by brushing $5 \%$ w/v Aquazol ${ }^{\circledR}$ 200, 1\% w/v and 0.6\% w/v Funori. However, according results, in samples exposed to two cycles of $75 \%$ $\mathrm{RH}, 5 \% \mathrm{w} / \mathrm{v}$ Aquazol $^{\circledR} 200$ and $1 \% \mathrm{w} / \mathrm{v}$ Funori resulted in a minor increase of gloss than the $0.6 \% \mathrm{w} / \mathrm{v}$ Funori, having values between 0.23 and 0.27 of total lightness $\left(\Delta L^{*}\right)$. Both became slightly darker after the two cycles of $75 \% \mathrm{RH}$ exposure. According to Ebert et al. (2012), the minor increase in gloss due to Aquazol ${ }^{\circledast}$ consolidation could be reversed without affecting the consolidation, by very gently dabbing the surface with a small cotton swab dipped in propan-2-ol.

Arsnagoglu (2005) showed that the complexes formed after dryness of Aquazol ${ }^{\circledR}$ in paint are less soluble and less reactive to high $\mathrm{RH}$. Furthermore, paint consolidated with Aquazol ${ }^{\circledR}$ shows no discoloration when aged (Wolbers et al., 1998; Arslanoglu, 2003; Lechuga, 2011) and a tendency to de-polymerize (Wolbers et al., 1998; La Nasa et al., 2017). This may imply less risk in terms of becoming insoluble with age, but may cause a decrease in tensile strength in the longterm (Wolbers et al., 1998). Additionally, most of the sargas produced during the sixteenth century do not have a ground layer, thus the adhesive would not be required to penetrate to any great extent. While viscosity may limit penetration, it would not be beneficial to use a consolidant that could form a film on surface, altering their matte appearance. Nevertheless, a consolidant with very low viscosity may disturb the fragile paint and displace unbound pigment, as well as soaking into the fabric (Ebert et al., 2012). Especially for large format paintings such as a Lenten veil, flexibility might be a principal requirement if they are not mounted on a stretcher, or are rolled for long periods. However, not all distemper paintings, in whatever format, have the same needs. Some have a stretcher or strainer, such those within an organ, shutter or altarpiece door, while others are without framing support, such as imitation of tapestries, Lenten veils or curtains.

Nikolaus mentions in his book (1999:220) that artificial resins in organic solvents can initially penetrate well, but during evaporation of the solvent they are partially retransported to the surface. Thus, the viscosity of the binding agent is very important and the higher viscosity, the lower the penetration. The presence of micro-fissures, crazing, micro-cracking and voids in the painted surface also results in blanching or optical whitening effects due to light scattering. Moreover, the study of La Nasa et al. (2017:518) highlights that the stability of the polymer is affected by the presence of pigments. This fact corresponds with the results in this study. In general, both types of Aquazol ${ }^{\circledR}$ presented higher fluctuations in terms of colour change and gloss when subjected to different $\mathrm{RH}$ conditions. The slight darkening observed in some samples could depend on the pigment and its absorbency. Charcoal is especially absorbent. Nevertheless, discolouration of samples in this study was not great but there were great differences in terms of gloss.

As Colombo et al. (2015:4) have pointed out, the application of a consolidant on a substrate can both lower the pigment volume concentration (PVC) and smooth the surface, making the paint appears more saturated and darker. A matte, porous paint has a PVC above the critical pigment volume concentration (CPVC). The reason behind darkening is connected to the way that diffusely reflected light is perceived. Above the CPVC, the amount of binder is decreased and pigment particles stick out above the surface of the binder, becoming rougher and causing the diffusion or scattering of the light when hitting the surface (Hansen et al., 1993). A high pigment concentration volume on the paint surface can result in a porous layer and can easily absorb consolidant solutions, resulting in a possible discoloration (Hansen et al., 1993).

Nevertheless, according to Lechuga (2011), penetration of a porous substrate is advantageous when consolidating friable paint detached from the priming as it helps to achieve a good adhesion not just on surface but between coats. This has been observed in studies by Welsh (1980) when consolidating powdery matte paint, as well as by Trimpler and co-authors (1996, cited in Chapman and Mason, 2003:386). They used a combined mixture of de-ionised water and propan-2-ol, instead of only propan-2-ol: 'it appeared that the use of the slow evaporator had two beneficial effects: it prevented the formation of a skin, which occurs when a fast evaporating solvent is used and the consolidant solution begins to dry before penetrating the paint. It also avoided the poultice like effect of a fast evaporating solvent drawing the resin to the surface during drying' (Welsh 1980: 4).

On the other hand, Funori, presented the most similar characteristics to those of an original distemper painting (made with animal glue and pigments). Both concentrations $(0.6 \%$ and $1 \%)$ caused the fewest changes in appearance together with $5 \%$ Aquazol $^{\circledR} 200$, but adhesion was among the tested adhesives. This study confirmed that Funori is a stronger consolidant than the other resins tested, with sufficient consolidation at lower concentrations in deionised water than the concentrations of the other resins in their corresponding solvents. However, Funori requires more preparation time, and must be applied warm, which make its usage suitable for controlled environments. It furthermore lasts only a few days before developing mold and its final properties can differ greatly depending on the recipe and ways to purify the algae (Michel 2011; Fan 2012). Concentrations of Funori also form stains or tide lines, coinciding with studies of Catenazzi (2016). In contrast, due to the brittle nature of the adhesive as well as the paint in sargas, the application of Funori increased the tendency to fracture and detach paint upon application. Its brittleness is the main concern if using it to consolidate sargas. 


\section{Conclusion}

This study involved making historically accurate reconstructions, following Nuñez and Pacheco's treatises with descriptions of sargas. Samples derived from these reconstructions, improved understanding of the technical characteristics of sargas while new and issues that arise as they age. Therefore, informed explanations of the different phenomena affecting such paintings can provide future conservators with a better starting point for conservation treatments.

By testing and comparing a number of traditional and modern adhesives and established methodologies for the consolidation of matte paint, it was possible to design and conduct a comparative study of consolidation on historical reconstructions. The study also allowed evaluation of the behaviour of the consolidated reconstructions after exposure to different $\mathrm{RH}$ cycles, allowed the impact of the adhesives on painted surfaces to be assessed. Overall, this study has provided valuable information that can aid conservators in dealing with consolidation issues on distemper canvas paintings.

Aquazol $^{\circledR} 2005 \%$ and Funori $1 \%$ were considered most promising, but environmental conditions should be evaluated prior to using them. However, this initial study was limited in scope and if repeated, certain aspects could be improved, including testing more materials and techniques of application. Additionally, great differences between results obtained with Aquazol ${ }^{\circledR} 200$ $3 \%$ and $5 \%$ were observed. Further research should be performed to test in-between concentration, maybe a $4 \%$ $\mathrm{w} / \mathrm{v}$ and tests could benefit from a constant monitoring environment with controlled temperature and humidity measurements.

In terms of removability, practically all adhesives and coatings are absorbed within the structure of a painting (Appelbaum, 2007). Therefore, only highly stable, nonyellowing, thermoplastic polymers (and thus, retreatable) should be used as there is an impossibility of removing the material once is well distributed on the paint layer. Changes that may occur after consolidation can be minimized, though not necessarily prevented

\section{References}

APPELBAUM, B. (2007). Conservation Treatment Methodology, Oxford: Elsevier.

ANDRINA, E. (2014). "Potentiality of Funori to restore physical breaks of deteriorated cellulosic fibers", CeROArt [accessed 21/10/2016]. Available at: http://ceroart.revues.org/3899

ARSLANOGLU, J. (2003). “Evaluation of the Use of Aquazol as an Adhesive in Paintings Conservation", Western Association for Art Conservation Newsletter, 25(2):12-18.
ARSLANOGLU, J. (2004). "Aquazol as Used in Conservation Practice" Western Association for Art Conservation, 26: 10-15.

ARSLANOGLU, J. (2005). "Using Aquazol: A Brief Summary"' American Institute for Conservation of Historic and Artistic Works Paintings Specialty Group Postprints, 17:107-110.

BOMFORD, D., ROY, A. \& SMITH, A. (1986). "The Techiques of Dieric Bouts: Two Paintings Contrasted", National Gallery Technical Bulletin, 10:39-57.

BORREGO DÍAZ, P., BUCES AGUADO, J. A. \& CARRASCO DAMIÁN, S. (2001). Proceso de Conservación del aguazo "Oración en el Huerto", Pátina II, 10: 4-11.

BUCES AGUADO, J. A. (2001). “La sarga y el aguazo: dos técnicas pictóricas a examen", Revista Pátina, Madrid: Escuela Superior de Conservación y Restauración de Bienes Culturales, 10-11: 5870 .

BUCES AGUADO, J. A., AHIJÓN PRADO, M. J., CEÑAL GONZÁLEZFIERRO, A., LLORCA GARRIGÓS, C., MANZANARES ORTIZ, C., RETANA GARRIDO, C., \& YAÑEZ VINARDELL, M. C. (1992). “La Virgen y San Gabriel. Criterios de intervención de dos sargas de la Iglesia parroquial de San Pedro de Ávila", IX Congreso de Conservación y Restauración de Bienes Culturales, Sevilla, 557-570.

BRUQUETAS GALÁN, R. (2002). Técnicas y materiales de la pintura española en los siglos de oro, Madrid: Fundación de Apoyo a la Historia del Arte Hispánico.

CALVO, A., RODRíGUEZ DE AUSTRIA, L. \& MANSO, B. (2002). "Nuevas Aportaciones al Estudio de las Técnicas en la Pintura de Sargas (La Sarga de Santa Ana de la Iglesia Parroquial de Madarcos de la Sierra, (Madrid)", actas del I Congreso del GEIIC Valencia, 449454.

CASTELL AGUSTÍ, M. (2002). “Antecedentes Históricos y Técnicos del Soporte Textil: Las Sargas o Tüchlein. El Caso de los Telones Cuaresmales en la Iglesia de San Lucas Evangelista de Cheste (Valencia). Estudio Técnico, Analítico y Estado de Conservación", Actas del XIV Congreso de Conservación y Restauración de Bienes Culturales, Valladolid, 503-512.

CASTELL AGUSTÍ, M., MARTíN REY, S. \& FUSTER LÓPEZ, L. (2006) "Sargas o Tüchlein: Particularidades Técnicas y Alteraciones Frecuentes", Arché, Instituto Universitario de Restauración de la UPV,Valencia, 1: 79-86.

CATENAZZI, K. (2016). "Evaluation of the use of Funori for consolidation of powdering paint layers in wall paintings", Studies in Conservation, 62: 96-103. https://doi.org/10.1080/00393630.20 $\underline{15.1131043}$

COLOMBO, A., TASSONE, F., MAURI, M., SALERMO, D., DELANEY, J.K., PALMER, M. R., DE LA RIE, R., \& SIMONUTTI, R. (2012). “Highly transparent nanocomposite films from water-based poly (2-ethyl2-oxazoline)/TiO2 dispersions", RSC Advances, 2(16):6628-6636. https://doi.org/10.1039/C2RA20571H 
COLOMBO, A., GHERARDI, F., GOIDANICH, S., DELANEY, J. K., DE LA RIE, E. R., UBALDI, M. C., TONIOLO, L. \& SIMONUTTI, R. (2015). "Highly transparent poly (2-ethyl-2-oxazoline)TiO2 nanocomposite coatings for the conservation of matte painted artworks", RSC Advances, 103:84879-84888. https://doi. org/10.1039/C5RA10895K

DIGNARD, C., DOUGLAS, R., GUILD, S., MAHEUX, A. \& MCWILLIAMS, W. (1997). "Ultrasonic Misting. Part 2, Treatment Applications", Journal of the American Institute for Conservation, 36 (2):127-141. https://doi.org/10.2307/3179827

EBERT, B., SINGER, B. \& GRIMALDI, N. (2012). "Aquazol as a consolidant for matte paint on Vietnamese paintings"' Journal of the Institute of Conservation, 35(1): 62-76. https://doi.org/10.1080 $\underline{/ 19455224.2012 .672813}$

FAN, T. F. (2012). 'Evaluation of Funori Stability in Preparation Methods'. In: Barros, A., Bone, L., Clarricoates, R. \& Ghent A. eds. Adhesives and Consolidants in Painting Conservation. London: Archetype Publications in association with the ICON Paintings Group, 53-60.

GARCÍA GÓMEZ-TEJEDOR, J. (1991). 'Tratamiento de Conservación y Restauración', in El retablo y la sarga de San Eutropio de El Espinar, Dirección General de Bellas Artes y Archivos, Instituto de Conservación y Restauración de Bienes Culturales, Madrid: Ministerio de Cultura, 166-170.

GEIGER, T. \& MICHEL, F. (2005). "Studies on the Polysaccharide JunFunori Used to Consolidate Matt Paint", Studies in Conservation, 50(3):193-204. https://doi.org/10.1179/sic.2005.50.3.193

HANSEN, E. F. \& LOWINGER, R. (1990). "Investigations into Techniques for the Consolidation of High pigment Volume Concentration paint at the Getty Conservation Institute", Western Association for Art Conservation Newsletter, 12(3):13-16.

HANSEN, E. F., LOWINGER, R. \& SADOFF, E. (1993). “Consolidation of Porous Paint in a Vapour-Saturated Atmosphere. A Technique for Minimizing Changes in the Appearance of Powdering, Matte Paint", Journal of the American Institute for Conservation, 32(1): 1-14. https://doi.org/10.1179/019713693806066519

HANSEN, E. F., S, WALSTON, \& M. H. BISHOP (1993). Matte Paint: Its History and Technology, Analysis, Properties, and Conservation Treatment with Special Emphasis on Ethnographic Objects, Getty Conservation Institute in association with the International Institute for Conservation of Historic and Artistic Works (IIC), London.

HESS, D., AND ESER, T., (2012). Der Frühe Dürer, Nurenberg: Ausstellung im Germanischen Nationalmuseum. 24 (2).

HORIE, C.V. (2012). Materials for Conservation, Oxford: Butterworth $\&$ Co.

LA NASA, J., DI MARCO, F., BERNAZZANI, L., DUCE, C., SPEPI, A., UBALDI, V., DEGANO, I., ORSINI, S., LEGNAIOLI, S., TIN, M. R.,
DE LUCA, D., \& MODUGNO, F. (2017). "Aquazol as a binder for retouching paints. An evaluation through analytical pyrolusis and thermal analysis", Polymer Degradation and Stability, 144:508-519. https://doi.org/10.1016/j.polymdegradstab.2017.09.007

LECHUGA, K. (2009). "Aquazol as a Heat Set Adhesive for Textile Conservation Treatments", American Institute for Conservation of Historic and Artistic Textile Specialty Group Postprints, 19:1-7.

LECHUGA, K. (2011). "Aquazol-Coated Remoistenable Mending Tissues". In: CCI Symposium on Adhesives and Consolidants for Conservation: Research and Applications Proceedings, October, Canadian Conservation Institute, 1-14.

LEONARD, M., PREUSSER, F., ROTHE, A. \& SCHILLING, M. (1988). “Dieric Bouts's 'Annunciation'. Materials and Techniques: A Summary", The Burlington Magazine, 130 (1024): 517-522.

LEVENFIELD LAREDO, C. (1992). “Las Pinturas sobre Anjeo o Sargas. Historia Material y Técnica", in El retablo y la sarga de San Eutropio de El Espinar, Dirección General de Bellas Artes y Archivos, Instituto de Conservación y Restauración de Bienes Culturales, Madrid: Ministerio de Cultura, 152-157.

MAHEUX, A. F. \& MCWILLIANS, W. (1995). "The Use of Ultrasonic Mister for the Consolidation of a Flaking Gouache Painting on Paper". In: The Book and Paper Group Specialty Group Session, Vol 14, The American Institute for Conservation 23th Annual Meeting, June 1-4, Minnesota. Available at: http://cool.conservation-us.org/ coolaic/sg/bpg/annual/v14/bp14-03.html. [accessed 25/06/2017]

MICHALSKI, S. \& DIGNARD, C. (1997). "Ultrasonic Misting. Part 1, Experiments on Appearance Change and Improvement in Bonding", Journal of the American Institute for Conservation, 36 (2) :109-126.

MICHALSKI, S., DIGNARD, C., VAN HANDEL, L. \& ARNOLD, D. (1998). "The Ultrasonic Mister: Applications in the Consolidation of Powdery Paint on Wooden Artifacts". In: Dorge, V. and Howlett, F. C. eds. Painted Wood: History and Conservation, Proceedings of a Symposium organized by the Wooden Artifacts group of the American Institute for Conservation of Historic and Artistic Works and the Foundation of the AIC, Williamsburg, 11-14 November, The Getty Conservation Institute Publications, 498-513.

MICHEL, F. (2011).'Funori and JunFunori:Two Related Consolidants with Surprising Properties'. In: Adhesives and Consolidants for Conservation: Research and Applications, Canadian Conservation Institute Symposium Proceedings, October, Ottawa, 1-15.

PACHECO, F. (1649). Arte de la pintura, Madrid: Ed. Cátedra.

PALOMINO DE CASTRO Y VELASCO, A. (1715-1724) El Museo Pictórico y Escala Óptica, Vol I: Theorica de la Pintura, Madrid: Ed. Aguilar.

RENARD GROSS, P., BUCES AGUADO, J. A. \& FUSTER SABATER, M. D. (1991). "Camino del Calvario. Estudio y conservación de una sarga del Panteón Real de Oña (Burgos)", Servicio Central de 
Publicaciones del Gobierno Vasco, Vitoria-Gasteiz, 579-612.

ROY, A. (1988). “The Technique of a 'Tüchlein' by Quinten Massys" National Gallery Technical Bulletin, 12:36-43.

SARTIANI, O., SEVERINI, L., ROMA, P. \& CIATTI, M. (2010). "An Unusual Case of Integration and its Solution". In: Ellison, Smithen \& Turnbull eds. Mixing and Matching. Approaches to Retouching Paintings. London: Archetype.

SANTOS GÓMEZ, S. \& SAN ANDRÉS MOYA, M. (2004). “La Pintura de Sargas", Archivo Español de Arte, 77(305): 59-74.

SHARPE, E. (2016). "Restorers use Japanese algae and sturgeon glue to treat Futurist work. Giacomo Balla's Automobile Speed + Light + Noise to go back on view in Zurich", published in Journal The Art Newspaper. Available at: http://theartnewspaper.com/ news/conservation/restorersusejapanesealgaeandsturgeongluetotreatfuturistwork/[accessed 07/06/2017]

SWIDER, J. R. \& SMITH, M. (2005). "Overview of a 300-Year-Old Consolidant", Journal of the American Institute for Conservation, Vol. 44(2): 117-126.

TOMASINI, E., SIRACUSANO, G., \& MAIER, M. S. (2011). "Spectroscopic, Morphological and Chemical Characterization of Historic Pigments Based on Carbon. Paths for the Identification of an Artistic Pigment", Microchemical Journal, 102: 28-37.

THUER, C. (2012). "Facing Adhesives for Size-tempera Painted Wood: Results of a Research Internship for Historic Scotland". In: Barros D'Sa, A., Bone, L., Clarricoates, R. \& Gent, A. eds. Adhesives and Consolidants in Painting Conservation. London: Archetype, 6884.

VELIZ, Z. (1986). Artist's Techniques in the Spanish Golden Age. Six Treatises, Cambridge: Cambridge University Press.

VON DER GOLTZ, M., BIRKENBEUL, I., HOROVITZ, I. BLEWETT, M. AND DOLGIKH, I. (2012). "Consolidation of Flaking Paint and Ground". In: Hill Stoner, J and Rushfield, R. eds. Conservation of Easel Paintings. London: Routeledge, 369-383.

WATKINS, S. (2002). "Practical Considerations for Humidifying and Flattening Paper", The Book and Paper Group Annual 21: 61-76.

WELSH, E. (1980). "A Consolidation Treatment for Powdery Matte Paint", AIC Preprints of Papers Presented at the Eighth Annual Meeting, San Francisco, California, 22-25 May, 141-150.

WOLBERS, R., D. DUERBECK, \& M. MCGINN (1998). "Poly (2-Ethyl2-Oxazoline): A New Conservation Consolidant". In: Dorge, V. \& Howlett, C. ed. Painted Wood: History and Conservation. Los Angeles: The Getty Conservation Institute, 514-527.

WOLFTHAL, D. (1989). The Beginnings of Netherlandish Canvas Painting 1400-1530, Cambridge Univ. Press.

\section{Author/es}

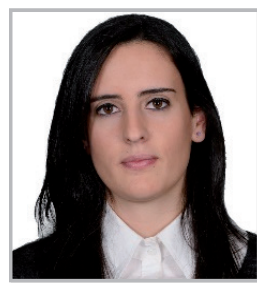

Cristina Castro Simarro

ccsimarro@gmail.com

Restauradora

Cristina Castro Simarro se graduó en el Máster de Conservación de Pinturas de Caballete en la Universidad de Northumbria en 2017. Asimismo, ha realizado los estudios de Historia del Arte en la Universidad Complutense de Madrid y de Conservación y Restauración de Bienes Culturales en la especialidad de pintura en la Escuela Superior de Conservación y Restauración de Bienes Culturales de Madrid (ESCRBCM). Después de graduarse, participó en varios programas de formación práctica. En 2013 se formó en el Instituto Andaluz del Patrimonio Histórico (IAPH), participando en el proyecto de restauración del "Conjunto pictórico Casa Juan de Arquijo" y continuó en Oporto, Portugal, donde participó en la implementación de un plan de conservación de una tela de altar del siglo XIX. Entre otros trabajos recientes, campañas de restauración y otras prácticas formativas, trabaja de forma autónoma y recientemente ha finalizado el Máster de Formación del Profesorado para cuyo trabajo final se ha centrado en la educación patrimonial.

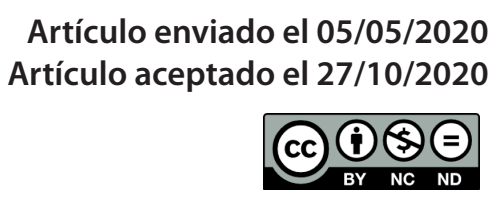

https://doi.org/10.37558/gec.v18i1.766 